\title{
PERMISSIBLE CONSTITUTIONAL REQUIREMENTS FOR THE ENFORCEMENT OF PUBLIC LIABILITY AFTER THE REPEAL OF THE LAW ESTABLISHING IT (on the example of liability for failure to submit calculation of social insurance fee)
}

\author{
Sergey D. Knyazev \\ Far Eastern Federal University, Vladivostok, Russia
}

\section{Article info}

Received - 2018 December 23

Accepted - 2019 February 25

Available online - 2019 April 20

\section{Keywords}

Temporal effect of legislation, increased responsibility, mitigation of liability, the removal of responsibility, prosecution, law repealed, the constitutional standards of public-legal responsibility, social insurance fees, the failure to submit the calculation of social insurance fees, the abolition of the law
The subject of the paper is temporal effect of abolition of the law establishing liability (especially liability for failure to submit calculation of social insurance fee).

The main aim of the paper is to confirm or disprove the hypothesis that the application of the rule of liability after its repeal depends on whether the law has introduced a rule on a similar offense and what is its objective side. The author wants to apply this hypothesis to the Russian legislation concerning liability for failure to submit calculation of social insurance fee.

The description of methodology. The author uses economic approach and the theory of rational choice as well as the dialectic and formal-legal methodology. The author uses general scientific methods (analysis, synthesis, description) as well as particular academic legal methods (formal-legal method, interpretation of legal acts.

The main results and scope of their application. Temporal rules have universal general legal value, they must be applied to all types of legal liability. The repeal of the law establishing liability blocks generally the possibility of applying such law in the future. When the repeal of a law providing for liability for a specific offence is accompanied by the adoption of another law on liability, it does not entail the cancellation, but strengthening or mitigation of liability. If the repeal of the law establishing liability is intended to "transform" the legal (sectoral) nature of liability, it is permissible to apply the revoked law to persons who have committed the offence according to this law before its cancellation. The adoption of a law that mitigates liability requires its extension to those who have committed the relevant unlawful act before the new law is introduced. The legal rules abolishing one type of liability for a particular offence and establishing a more or less strict liability of another type should enter into force simultaneously, without any time gap. Otherwise the repeal of the law establishing liability would undoubtedly "nullify" the possibility of holding someone liable for the relevant offence that occurred prior to the repeal.

According to pt. 1 of art. 119 of the Russian Tax Code failure to submit the calculation of social insurance fees constitutes an offense only if these contributions themselves were not paid in full in a timely manner. After the Federal law "On social insurance fees... " have been revoked since January, 1, 2017 the failure of the payer of social insurance fees to submit the calculation of accrued and paid insurance fees ceased to be considered by the legislator as an offense. Ergo since that date holding someone (who had already paid social insurance fee) to responsibility for non-submitting the calculation shall be completely excluded. The results of research may be used as the basis of correction of temporal rules in any legal system to make enforcement more just.

Conclusions. The author confirmed the hypothesis that the application of the rule of liability after its repeal depends on whether the law has introduced a rule on a similar offense and what is its objective side. After the cancellation of Federal law "On social insurance fees...", the article of the Russian Tax Code replaced this law does not provide for liability for failure to submit calculation, when payment of the social insurance fee was made on time. And persons who did so can not take any legal responsibility. 


\section{Introduction.}

At first glance, the wording contained in Article 54 (part 2) of the Constitution of the Russian Federation means nothing more than a fundamental prohibition of bringing someone to responsibility for an act previously considered illegal and punishable, after the abolition of the law declaring it as such. At the same time, however, it is important to take into account that, as has been repeatedly noted by the constitutional Court of the Russian Federation (resolution No. 20-P of 14 July 2015, No. 23-P of 14 June 2018, etc.), the abolition of the relevant law should really have the legal effect of absolute elimination of responsibility for a specific offense, and not its change (mitigation or strengthening); otherwise, the person who committed the said offense during the period of the law may not claim automatic exclusion from the list of subjects of liability provided for by the "old" (with increased liability) or "new" (with mitigation of liability) law.

The above - mentioned rules, which follow from the mentioned constitutional provision - seem to fully guarantee an unambiguous and fair solution to the issue of the limits of liability, including public liability, in any legislative "perturbations" concerning its grounds, types and sizes. Nevertheless, law enforcement practice often shows that both casual interpretation and applied implementation of these rules are sometimes faced with very serious difficulties, a clear confirmation of which can be the Decision of the constitutional Court of the Russian Federation of February 17, 2018 № 3-P.

2. Legal characteristic of the Resolution of the Constitutional Court of the Russian Federation of February 17, 2018 № 3-P.

This Resolution the Constitutional Court of Russia once again was compelled to address a problem of admissibility of attraction to public-legal responsibility after cancellation, establishing its law, those persons who "managed" to make the offense provided by it before the specified cancellation. The need to consider the relevant case was dictated, in fact, by the fact that with the adoption of the Federal law of July 3, 2016 250-FZ "On amendments to certain legislative acts of the Russian Federation and the annulment of certain legislative acts (provisions of legislative acts) of the Russian Federation in connection with the adoption of the Federal law "On amendments to parts one and two of the Tax code of the Russian Federation in connection with the transfer to the tax authorities of the administration of insurance contributions for compulsory pension, social and health insurance" (the Federal law of July 3, 2016 № 250-FZ) from January 1, 2017, the Federal law of July 24, 2009 № 212-FZ "On insurance contributions to the Pension Fund of the Russian Federation, the social insurance Fund of the Russian Federation, the Federal compulsory health insurance Fund", according to part 1 of Article 46 of which the failure of the payer of insurance premiums within the prescribed period of calculation for accrued and paid insurance premiums to the control body for payment of insurance premiums at the place of registration entails a penalty of 5 percent of the amount of insurance premiums, accrued for payment for the last three months of the reporting (settlement) period, for each full or partial month from the date established for its submission, but not more than 30 percent of the specified amount and not less than 1000 rubles.

As a result of these changes made by the Federal legislator, all interested bodies and officials inevitably faced the question of the possibility of bringing after January 1, 2017 payers of insurance premiums to responsibility for their Commission before the specified date of the offense provided for in part 1 of Article 46 of the repealed Federal law. It is no accident that one of the authors of the appeals, which were the reason for its resolution by the Constitutional Court of Russia, was - along with the limited liability company "Prospect" - the Arbitration court of Moscow, which considered contrary to the Constitution of the Russian Federation, its Article 54 (part 2), any application after January 1, 2017 of part 1 of Article 46 of the Federal law № 212-FZ "On insurance contributions to the Pension Fund of the Russian Federation, the social insurance Fund of the Russian Federation, the Federal compulsory health insurance Fund".

Omitting all the details and details of the study conducted by the Constitutional Court, it can be stated that the Court concluded that the loss from 1 January 2017 of the Federal law "On insurance contributions to the Pension Fund of the Russian Federation, the social insurance Fund of the Russian Federation, the Federal compulsory health insurance Fund" did not entail the elimination of responsibility for the act provided for in part 1 of its Article 46, as actually from this date responsibility for such act has to come under point 1 of Article 119 of the Tax code of the Russian Federation providing that failure to submit within the prescribed 
period of the tax Declaration (calculation of insurance premiums) to the tax authority at the place of registration shall entail a fine in the amount of 5 percent of the amount of tax (insurance premiums) not paid within the prescribed period, payable (surcharge) on the basis of this Declaration (calculation of insurance premiums), for each full or partial month from the date established for its submission, but not more than 30 percent of the specified amount and not less than 1000 rubles.

According to the constitutional Court of Russia, despite some legal nuances (the transfer of the regulation of insurance contributions to the legislation on taxes and fees, the transfer of authority for control over their payment to the tax authorities, the change in the method of calculation of the fine imposed) being the wrongful act, the responsibility for which is before January 1, 2017 was established by part 1 of Article 46 of the Federal law "On insurance contributions to the Pension Fund of the Russian Federation, Fund of social insurance of the Russian Federation, Federal Fund of compulsory medical insurance», and after January 1, 2017 was provided for by part 1 of Article 119 of the Tax code of the Russian Federation, remained unchanged. As a result, this means that from January 1,2017 , either part 1 of Article 46 of the repealed Federal law or part 1 of Article 119 of the said Code can be applied to such offenses that took place before this date; moreover, the choice of one of these legislative provisions for the purpose of applying the measure of responsibility for the relevant offense is exhaustively predetermined by the requirements of Article 54 of the Constitution of the Russian Federation.

Proceeding from this, the termination of the Federal law "On insurance contributions to the Pension Fund of the Russian Federation, the social insurance Fund of the Russian Federation, the Federal compulsory health insurance Fund" from 1 January 2017 does not prevent the application of part 1 of its Article 46 from the specified date to acts committed before its occurrence (i.e., during action of this Federal law) only if in system of the operating legal regulation taking into account the actual circumstances of the specific case the size of the penalty calculated according to the called legal provision is less or equal to the size of the penalty calculated according to part 1 of Article 119 of the Tax code of the Russian Federation in interrelation with General provisions of the legislation on responsibility for Commission of tax offenses.
In other cases - and it was also directly pointed out by the constitutional Court of the Russian Federation the application to the relevant acts, including the courts considering claims challenging the fines for failure to file within the prescribed period for the calculation of accrued and paid insurance contributions imposed under part 1 of Article 46 of the Federal law "On insurance contributions to the Pension Fund of the Russian Federation, Fund of social insurance of the Russian Federation, Federal Fund of compulsory medical insurance" should be subject to part 1 of Article 119 of the Tax code of the Russian Federation [1-2].

Taking into account the importance of the decisions of the constitutional Court of the Russian Federation, and especially the legal positions formulated in them [3-6], in order to ensure the constitutional order, it is hoped that the Resolution No. 3-P of 17 January 2018, adopted by it, will undoubtedly have a noticeable orienting effect on jurisdictional law enforcement practice in order to bring it into harmonious compliance with the constitutional standards of legal responsibility.

\section{Constitutional and legal characteristics of the abolition of the law establishing liability.}

When understanding and assessing the constitutional and legal meaning of this Decision (without rejecting its conceptual role and case-law), it is impossible not to pay attention to the following.

First of all, it should be emphasized that, firstly, the provisions enshrined in Article 54 of the Constitution of the Russian Federation, defining the rules of action in time of the laws establishing, changing or eliminating responsibility for offenses, have universal legal significance, are subject to mandatory accounting for all types of legal liability and, consequently, inevitably have an impact on the regulatory parameters (limits) of their implementation.

Second, the repeal of the law establishing responsibility for a particular offense, blocks, as a General rule, the possibility of applying such a law in the future, including in respect of persons who committed an act (action, inaction) that fell under the signs of the relevant offense before its abolition; at the same time, in cases where the repeal of a law providing for liability for a specific offence is accompanied by the adoption of a law making the same offence a ground for a different - more or, on the contrary, less strict type of liability, it is necessary to be aware that such legislative changes do not entail the cancellation of 
liability, but its strengthening or mitigation.

Third, if the repeal of the law establishing liability does not mean the elimination of liability as such, but pursues the goal of "transforming" its legal nature, accompanied by a legal strengthening of coercive (restrictive) measures addressed to violators, it may under certain circumstances - make it permissible to apply the law to persons who have committed the offence provided for by it before its abolition.

Fourth, the adoption of the law mitigating responsibility objectively demonstrates the revision of the legislative attitude to the nature and degree of public danger of a wrongful act, and thus to the legal status of the perpetrators, which, of course, requires, based on the constitutional values of justice and humanism, its extension to those who committed the corresponding illegal act before the new law.

Fifth, when applying - in the situation of legislative transformation of the legal nature (type) of responsibility - the law that has lost its force, it should be taken into account that the legal norms abolishing responsibility of one type for a particular offense and establishing more or less strict liability of another type should enter into force simultaneously, without any temporary gap, as well as relate to the same act (the composition of the offense); under other circumstances, the repeal of the law establishing liability would undoubtedly "nullify" the possibility of holding someone liable for the relevant offence that occurred prior to the said repeal.

These considerations are based not only directly on the constitutional provisions, but also find confirmation in the legal positions repeatedly reproduced by the Constitutional Court of Russia in its legally binding decisions (decisions of April 20, 2006 № 4-P, July 14, 2015 № 20-P, February 10, 2017 № 2-P, etc.). Their adequate and correct perception is the imperative dominant of the proper constitutional and legal assessment of the legislative provisions that led to the abolition of Article 46 (part 1) of the Federal law "On insurance contributions to the Pension Fund of the Russian Federation, the social insurance Fund of the Russian Federation, the Federal compulsory health insurance Fund" and amendments to Article 119 (part 1) of the Tax code of the Russian Federation, in terms of the potential possibility of bringing to justice the payers of insurance contributions for the act committed before January 1 , 2017, falling under signs of Article 46 (part 1) of the called Federal law, after approach of this date.
4. Application of the constitutional and legal principles of the legislation on liability in time to the rules on liability for failure to pay insurance premiums.

In this context, we should initially start from the fact that the termination of the Federal law "On insurance contributions to the Pension Fund of the Russian Federation, the social insurance Fund of the Russian Federation, the Federal compulsory health insurance Fund" cannot be automatically considered, without any reservations, as entailing an obvious abolition of legal liability, which was established by its Chapter 6 "Violations of the legislation of the Russian Federation on insurance contributions and responsibility for their Commission", since in accordance with the Federal law "On amendments to parts one and two of the Tax code of the Russian Federation in connection with the transfer to the tax authorities of the authority to administer insurance premiums for mandatory pension, social and medical insurance" (Article 1), the Tax code of the Russian Federation was synchronously supplemented with the provisions providing from January 1, 2017 the offensive for violation of the legislation on insurance premiums of tax liability.

Therefore, understanding of legal prospects of bringing to responsibility of payers of insurance premiums for the act falling under signs of the offense provided by part 1 of Article 46 of the Federal law "On insurance contributions to the Pension Fund of the Russian Federation, social insurance Fund of The Russian Federation, Federal compulsory health insurance Fund" made before January 1 , after the specified date depends on whether this responsibility was really cancelled or underwent peculiar "reincarnation" in the tax legislation, namely in part 1 of Article 119 of the Tax code of the Russian Federation.

In the first approximation the bases of responsibility (structures of offenses) fixed by part 1 of Article 46 of the Federal law "On insurance contributions to Pension Fund of the Russian Federation, social insurance Fund of the Russian Federation, Federal compulsory medical insurance Fund" and part 1 of Article 119 of the Tax code of the Russian Federation in relation to violation of the legislation on insurance contributions are characterized by noticeable similarity or even identity of the legislative description, fixing and in one, and in other cases, the onset of liability for failure by the payer of insurance premiums within the statutory period of calculation of insurance premiums. But, if you look closely at the text of these two rules, it becomes clear that part 1 of Article 46 of the said Federal law 
qualifies as an offense the failure to submit to the monitoring body for the payment of insurance premiums within the prescribed period of calculation for accrued and paid insurance premiums (hence it is not accidental and its title - "Failure to provide calculation for accrued and paid insurance premiums").

As for part 1 of Article 119 of the Tax code of the Russian Federation (in force since January 1, 2017 edition), it establishes liability for failure to provide calculation on insurance premiums associated with non-payment (incomplete payment) in the period of insurance premiums provided by the legislation. At least, the aggregate perception (interpretation) of the dispositions and sanctions of this Article does not allow to come to a different conclusion, as they have not only not mentioned as a sign of the objective side of the offence, the timely payment of insurance premiums, but also clearly stated that the calculation of the amount of the penalty in percentage of not paid within the prescribed period, the amount of insurance premiums payable (paid) outstanding on the basis of the calculation. And though in law enforcement practice of arbitration courts the other version of understanding (interpretation) of part 1 of Article 119 of the Tax code of the Russian Federation assuming occurrence of responsibility for failure to provide the documents mentioned in it regardless of the fact of payment of the tax (insurance premiums) is extended, it is impossible not to recognize that on the authentic regulatory contents it nevertheless is calculated only on the cases connected with failure to provide the tax Declaration (calculation on contributions) together with non-payment - full or partial - the tax (insurance premiums).

The design of the objective party of structure of the offense provided by part 1 of Article 46 of the Federal law "On insurance contributions to the Pension Fund of the Russian Federation, social insurance Fund of the Russian Federation, Federal compulsory health insurance Fund", on the legally significant signs assumes accountability for violation of the established organizational order of public administration in the field of payment of insurance premiums[7, 20], directly not affecting financial interests of the corresponding public subject, when the failure to submit within the prescribed period for the calculation of insurance premiums has not prevented the timely calculation and payment, which is not typical for the basis of liability set out in part 1 of Article 119 of the Tax code of the Russian
Federation. After all, according to the latter, failure by the payer to pay the insurance premiums within the statutory period constitutes an offence only if these contributions themselves were not paid in full in a timely manner.

Here, probably, it is impossible to do without mentioning of Determination of the constitutional Court of the Russian Federation of December 16, 2008 No. 1069-0-O in which the conclusion was drawn that responsibility as regards 1 Article 119 of the Tax code of the Russian Federation for untimely submission of the tax Declaration is directed on protection of independent object of the relations in the field of the taxation connected with implementation of tax control and therefore has to come irrespective of the fact of payment by the taxpayer of the tax [8-9]. It is difficult to disagree with this: indeed, an impartial analysis of all elements of the said tax rule (as amended at the time of the adoption of the said Definition) did not give any grounds for opposing judgments.

However, after the Federal law of October 27, 2010 No. 229-FZ "About modification of part one and part two of the Tax code of the Russian Federation and some other legal acts of the Russian Federation, and also about recognition become invalid for separate legal acts (provisions of legal acts) of the Russian Federation in connection with settlement of debt on payment of taxes, fees, penalties and penalties and some other questions of tax administration" in part 1 of Article 119 of the Tax code of the Russian Federation serious specifications were made, provides a penalty of a percentage of the outstanding amount of tax payable (paid) on the basis of unrepresented within the prescribed period of the Declaration, given the legal position of the constitutional Court of the Russian Federation objectively needs in correlation with the available legal regulation.

It is thought that the legal methods of fixing of signs of structure of an offense demanded now by part 1 of Article 119 of the Tax code of the Russian Federation and sanctions for its Commission quite definitely pursue the purposes of cumulative legal protection as spheres of control of timely representation of documents necessary for its implementation, and financial interests of the relevant public subjects. Such legal regulation means, in essence, the refusal taken by the legislator to apply for failure to submit within the prescribed period of the tax Declaration (calculation of insurance premiums) sanctions, characteristic of property violations, in cases where the tax (insurance premium) was paid in a timely manner by the taxpayer 
(payer of the insurance premium), and therefore the threat to the financial interests of the public entity itself was not implemented.

Even taking into account the fact that the actual (current) paradigm of sanctions provided for by part 1 of Article 119 of the Tax code of the Russian Federation is far from legal and technical perfection, and, in addition, creates many difficulties in its comparison with the measures of responsibility established by part 1 of Article 122 of the same Code, it would be a great exaggeration to argue that the responsibility for the failure of the taxpayer (payer of the insurance premium) within the prescribed period of the tax Declaration covers the cases of failure to submit a tax return., not related to non-payment (incomplete payment) of tax (insurance premium).

\section{Conclusions.}

Accordingly, there is a reason to believe that after the loss of the force of the Federal law "On insurance contributions to the Pension Fund of the Russian Federation, the social insurance Fund of the Russian Federation, the Federal compulsory health insurance Fund" since January 1, 2017, the failure of the payer of insurance contributions within the statutory period of calculation of accrued and paid insurance contributions has ceased to be considered by the legislator as an offense; therefore, starting from this date, bringing the payer to responsibility for him both in part 1 of Article 46 of this Federal law and in part 1 of Article 119 of the Tax code of the Russian Federation - should be, if consistently guided by the provisions of Article 54 (part 2) of the Constitution of the Russian Federation, completely excluded.

Constitutional order in a legal state, as it follows from Articles 1 (a part 1), 15 (part 2) and 19 (part 1) of the Constitution of the Russian Federation, is inconceivable without universal compliance with the Constitution and laws, which - pursuant to the requirements laid down in its Articles 2, 17 (part 1), 18 and 45 (part 1) - must be, first and foremost, inherent in the bodies and officials of public authorities $[10,20]$. Of particular importance is the constitutional legality in their activities, for obvious reasons, in the establishment and application of legal responsibility $[11$, p. 16], with inevitability assuming compulsory restriction of the rights and freedoms of citizens and their associations (legal entities), possible according to Article 55 (part 3) of the Constitution of the Russian Federation only according to the Federal law and only to the extent it is necessary for protection of bases of the constitutional system, morals, health, the rights and legitimate interests of other persons, ensuring national defense and security of the state.

With this in mind, when bringing citizens and legal entities to responsibility, the jurisdictional bodies are obliged to strictly follow the legislative provisions and avoid their arbitrary - whatever it is motivated interpretation, in particular not to allow a broad interpretation of the grounds for such responsibility, not forgetting the content and meaning of the legal norms fixing it that they, by definition, cannot be anything accidental, superfluous or immaterial [12, p. 18]. Otherwise, in law enforcement, there will be a great risk of forming - in isolation from the true content of constitutional and legislative provisions - a parallel legal reality that claims to Autonomous existence and development, incompatible with the constitutional principles of the rule of law, the rule of law, the separation of powers and the equality of all before the law and the court [13, p. 8].

In conclusion, it is important to emphasize that the abolition of liability of payers of insurance premiums (legal entities, individual entrepreneurs) for failure to submit within the statutory period for the calculation of accrued and paid insurance premiums does not indicate an indifferent - from this moment - the attitude of the legislator to comply with the deadlines for the submission of payments on insurance premiums and does not cause a problem of complete impunity for ignoring them. It is possible to be convinced of it having addressed Article 15.5 "Violation of terms of submission of the tax Declaration (calculation on insurance premiums)" of the Code of the Russian Federation on administrative offenses according to which since January 1, 2017 (the Federal law of July 3, 2016 No. 250-FZ) violation of the established terms of submission of calculation on insurance premiums to tax authority in the place of accounting involves the prevention or imposition of an administrative penalty on officials in the amount of three hundred to five hundred rubles.

Thus, until January 1, 2017, the Federal legislator for failure to submit within the prescribed period of calculation for accrued and paid insurance premiums provided for the responsibility of the payers of insurance premiums themselves (part 1 of Article 46 of the Federal law "On insurance contributions to the Pension Fund of the Russian Federation, the social insurance Fund of the Russian Federation, the Federal compulsory health insurance Fund»), and from January 
ISSN 2658-4050 (Online)

1, 2017, he established the responsibility of their officials for such inaction (Article 15.5 of the Code of administrative offences of the Russian Federation). It seems that this decision does not go beyond the constitutional discretion of the legislature and can hardly be subject to constitutional censure.

To me, probably, can object, having referred to that this interpretation of the changes made by the Federal legislator concerning responsibility for noncompliance with terms of representation of calculations on insurance premiums, isn't consistent with its (legislator) true intentions which would be more correct to link not with in itself loss of the Federal law "On insurance contributions to the Pension Fund of the Russian Federation, social insurance Fund of the Russian Federation, Federal compulsory health insurance Fund" forces, and with the following "movement" of the most part of the normative material contained in the called Federal law in the Tax code of the Russian Federation. In anticipation of this, I think it is useful to remind all those who base their vision of legal norms mainly on their teleological origins, that often the true legislative goals (motives) can be judged only with a fair degree of probability (conditionality). Besides, law and order, doubtless, rather to verify their intentions, promoted by the legislator when generating (changing) legal regulations and with the established results of his legislative efforts.

Deciding on cancellation - for one reason or another - of the law establishing legal responsibility, to the Federal legislator (especially in cases when such cancellation is accompanied by emergence of the new law on similar responsibility) it is more preferable to establish the provisions in detail defining rules of attraction in "transition period" of the relevant persons to responsibility for earlier offenses committed by them (the Resolution of the constitutional court of the Russian Federation of July 14, 2015 No. 20-P). When it fails to properly "embed" regulatory novels in the legal regulation of liability in the field of taxes and fees (mandatory payments), the legal amendments (changes) can only generate additional costs regarding the interpretation of tax legislation, which already suffers from a noticeable inconsistency and gap [14, p. 3; 15, p. 16], and therefore the concern about ensuring the proper continuity of legislative policy in the field of public liability should not under any circumstances be carried out on a residual principle. 


\section{REFERENCES}

1. Shchekin D.M. Review of judicial practice of the Supreme Court of the Russian Federation and the Constitutional Court of the Russian Federation on tax disputes for December 2017 - January 2018. Vestnik ekonomicheskogo pravosudiya Rossiiskoi Federatsii, 2018, no. 3, pp. 63-71. (In Russ.).

2. Afanasiev S., Mednikov D. Review of legal positions in the decisions of the Constitutional Court of Russia.

Sravnitel'noe konstitutsionnoe obozrenie = Comparative Constitutional Review, 2018, no. 2, pp. 128-145. DOI: 10.21128/1812-7126-2018-2-128-145. (In Russ.).

3. Volkova N.S., Khabrieva T.Ya. Legal positions of the Constitutional Court of the Russian Federation and the Parliament. Moscow, Norma Publ., 2005. 176 p. (In Russ.).

4. Petrov A.A. Decisions of the Constitutional Court of the Russian Federation in the mechanism of legal regulation. Irkutsk, Institute of legislation and legal information of Irkutsk region Publ., 2007. 220 p. (In Russ.).

5. Romanov M.L. Decisions of the Constitutional Court of the Russian Federation as a source of administrative law, Cand. Diss. Thesis. Saratov, 2011. 26 p. (In Russ.).

6. Lomakina L.A. Impact of Legal Positions of the Constitutional Court of the Russian Federation on Development of Legislation on Administrative Responsibility. Zhurnal rossiiskogo prava = Journal of Russian Law, 2012, no. 2, pp. 61-68. (In Russ.).

7. Kobzar-Frolova M.N. Legal Regulation of Tax Legal Relations. Rossiiskoe pravosudie $=$ Russian Justice, 2018, no. 10, pp. 17-23. (In Russ.).

8. Sasov K.A. Tax justice in decisions of the Constitutional Court of the Russian Federation, Monograph. Moscow, Norma Publ., 2013. 256 p. (In Russ.).

9. Turkevich $P$. Bringing to tax liability for late submission of the income tax return for the reporting period in the arbitration process. Korporativnyi yurist, 2010, no. 11, pp. 55-60. (In Russ.). (In Russ.).

10. Aranovsky K.V., Knyazev S.D. Constitution and the security. Gosudarstvo i pravo, 2018, no. 1, pp. 17-28.

11. Knyazev S.D. Constitutional standards of administrative responsibility in the legal system of the Russian Federation. Administrativnoe pravo i protsess = Administrative Law and Procedure, 2014, no. 2, pp. 16-22. (In Russ.).

12. Kniazev S.D. Mind the thin line between statutory interpretation and addition of new statutory rules. Zakon, 2017, no. 10, pp. 6-19. (In Russ.).

13. Knyazev S.D. Stability of the Constitution and significance thereof for the modern Russian federalism. Konstitutsionnoe i munitsipal'noe pravo = Constitutional and Municipal Law, 2015, no. 1, pp. 4-12. (In Russ.).

14. Morozov E.V. Administrative responsibility for offenses in the field of taxation, Cand. Diss. Thesis. Omsk, 2009. 19 p. (In Russ.).

15. Kustov D. A. The constitutional aspects of violations of consistency in the tax-legal regulation. Nalogoved, 2016, no. 8, pp. 11-22. (In Russ.).

\section{INFORMATION ABOUT AUTHOR}

Sergey D. Knyazev - Judge of the Constitutional Court of the Russian Federation, Honoured Lawyer of the Russian Federation, Honoured Scientist of the

Russian Federation, Doctor of Law, Professor, Head, Chair of Constitutional and Administrative Law Far Eastern Federal University

8, Sukhanova ul., Vladivostok, 690091, Russia e-mail: kap@dvfu.ru

RSCl AuthorID: 344659 


\section{BIBLIOGRAPHICDESCRIPTION}

Knyazev S.D. Permissible constitutional requirements for the enforcement of public liability after the repeal of the law establishing it (on the example of liability for failure to submit calculation of social insurance fee). . Pravoprimenenie $=$ Law Enforcement Review, 2019, vol. 3, no. 1, pp. 5-14. DOI: 10.24147/25421514.2019.3(1).5-14. (In Russ.). 